\title{
Waarom verskil ons so oor wat die wil van God is? Opmerkings oor Christelike morele oordeelsvorming
}

\author{
D E de Villiers \& D J Smit
}

\section{ABSTRACT}

Why do we differ so much about the will of God? Comments on the formation of christian moral judgements.

A better understanding of the way in which moral judgements are made and moral decisions are taken may help to understand why Christians differ so much on moral issues. Protestant ethicists, however, have generally ignored these questions, for a number of reasons. Heinz Eduard Todt, a former professor in Social Ethics from Heidelberg, Germany, has done more than anyone else to put these issues on the agenda of protestant ethicists. The authors analyse the five most important aspects of his theory. The factors that contribute to moral disagreement among Christians are identified and illustrated with reference to the moral problem of poverty.

\section{INLEIDING}

Een van die fundamentele geloofsoortuiginge van Christene was nog altyd dat die wil van God die uiteindelike maatstaf vir al hul doen en late is. 'n Probleem waarmee Christene egter gekonfronteer word, is dat hul eie interpretasie van wat die wil van God in konkrete situasies is, dikwels verskil van dié van ander Christene. Soms tree die verskillende sienings van die wil van God, ofte wel die moreel juiste, op 'n baie duidelike en selfs onthutsende manier na vore. Christene in Suid-Afrika byvoorbeeld, het in die verlede besonder heftig verskil oor die morele aanvaarbaarheid al dan nie van versetmetodes soos boikotte, sanksies, protesoptogte, sabotasie en straatbomme. Vandag verskil hulle net so heftig oor die wettiging van aborsie op versoek en die afskaffing van die doodstraf.

Waarom verskil Christene so oor wat die wil van God is? Enige verklaring wat gebied word vir die voorkoms van teenstrydige sieninge van die wil van God, hang noodwendig nou saam met die beskouing wat 'n mens huldig van die wyse waarop die wil van God geken word. Die vertrekpunt van hierdie artikel is dat God sy wil nie op 'n onbemiddelde, direkte manier aan Christene openbaar nie. Christene leer die wil van God of die moreel juiste nie anders ken as in en deur ' $n$ proses van morele 
oordeelsvorming nie. Ten grondslag van hierdie vertrekpunt lê die oortuiging dat God (en Christus) in die nuwe bedeling sedert die Pinkstergebeure nie anders by die mens teenwoordig is as in die gestalte van die Heilige Gees nie. Daar is geen rede om die werking van die Heilige Gees en die aktiwiteit van die mens teenoor mekaar te stel nie. Die metafoor met behulp waarvan die teenwoordigheid van die Heilige Gees by die mens waarskynlik die beste omskryf kan word, is dié van "inwoning". Daarin dat die Heilige Gees by ons inwoon, werk Hy nie alleen op ' $n$ verborge wyse in en aan ons nie, maar ook met ons - in die sin van "saam met" ons. $\mathrm{Hy}$ skakel nie as $\mathrm{Hy}$ in of aan ons werk ons eie werksaamheid uit nie. Die kenmerkende van die werk van die Heilige Gees is juis dat Hy ons aan die werk sit, en wel op so ' $n$ wyse dat dit wat $\mathrm{Hy}$ in ons werk, altyd deur onsself as ons eie werk voltrek word'.

As die Heilige Gees nie anders werk as dat $\mathrm{Hy}$ die selfstandigheid van mense in hul handele en denke eerbiedig nie, moet ons ook daarvan uitgaan dat dit ewe-eens ten aansien van die kennisname van Gods wil die geval is. Ons moet aanvaar dat God in en deur die Heilige Gees ook ten aansien van die kennisname van sy wil alle kenvermoëns van mense inskakel en alle bewussynsaktiwiteite van mense aktiveer. Anders uitgedruk: ons moet aanvaar dat God sy konkrete wil nie anders aan Christene openbaar nie as in en deur die proses van morele oordeelsvorming, waarin hulle selfstandig tot 'n oordeel aangaande dit wat moreel juis is, kom.

Aanvaar ons egter dat die Heilige Gees mense volledig inskakel as Hy die wil van die Vader aan hulle te kenne gee, moet ons ook aanvaar dat ons nie vir ons kennis van Gods wil aanspraak kan maak op onfeilbaarheid en volledigheid nie. Om mense ten volle in te skakel, beteken om ook hul feilbaarheid en beperkte bevatlikheid in te skakel. Dit beteken onder andere dat ons ook ruimte daarvoor moet laat dat Christene soms teenstrydige sieninge kan hê van wat die konkrete wil van God is. Dit beteken ook dat ons ons tot ' $n$ analise van die proses van morele oordeelsvorming moet wend as ons die faktore wat bydra tot uiteenlopende morele oordele by Christene nader op die spoor wil kom².

'n Christelike etikus wat besondere aandag aan 'n analise van die proses van morele oordeelsvorming gegee het, is Heinz Eduard Tödt, vroeër professor aan die teologiese fakulteit van die Universiteit van Heidelberg, Duitsland. Aangesien ons daarvan oortuig is dat sy analise lig werp op die faktore wat bydra tot die verskillende sieninge wat Christene het oor die wil van God of die moreel juiste, gee ons daarvan 'n uitvoerige uiteensetting. In die uiteensetting word gedagtes uit verskillende van sy 
bydraes oor morele oordeelsvorming gekombineer ${ }^{3}$. By die uiteensetting van elkeen van die vyf vernaamste aspekte van die proses van morele oordeelsvorming wat Tödt analiseer, illustreer ons aan die hand van die morele probleem van armoede hoe Christene tot uiteenlopende morele beslissings kan kom.

\section{TÖDT OOR DIE STAPPE VAN MORELE OORDEELS- VORMING}

Tödt onderskei ses sogenaamde aspekte of stappe (hy noem dit "Sachmomente" of "Schritte") in die proses van morele oordeelsvorming4. Die term "aspekte" of "fasette" is miskien beter, omdat dit die misverstand kan help vermy dat dit om 'n soort volgorde gaan. Wat ter sprake is, is hoegenaamd nié stappe wat in tydsorde op mekaar volg, of 'n soort innerlike, psigologiese proses beskryf wat in die etiese subjek voltrek word nie. Dit gaan eerder om ses fasette wat duidelik word wanneer 'n mens terugkyk op etiese beslissings wat gevel is en vra wat die oorwegings was wat 'n rol gespeel het, watter faktore in ag geneem is, watter aspekte bygedra het tot die uiteindelike standpuntinname.

Normaalweg, sê Tödt, geskied konkrete oordeelsvorming in die vorm van 'n soort herhalende proses: Die morele subjek of agent, wat moet besluit wat om te doen, kan by enige van die fasette begin dink. Die ander fasette word dan, bewustelik of onbewustelik, ook in gedagte geneem, en hulle beïnvloed en verander dalk weer die oortuigings aangaande die vroeëre fasette. So, in 'n heen-en-weer-proses van meesal onbewuste oorwegings, kom die morele agent uiteindelik tot 'n standpuntinname en tot optrede. Kortom, dit gaan nie om stappe van 'n kronologiese of psigologiese proses nie, dog om aspekte van 'n metodies geordende, ideaaltipiese proses van morele oordeelsvorming.

Die doel van so ' $n$ analise is om ' $n$ mens self van die meestal onbewuste fasette bewus te mak, sodat ' $n$ mens sowel jou eie as ander mense se standpunte en keuses beter kan verstaan en daarmee ook beter kan verstaan waar die werklike verskille tussen ons en hulle dalk lê.

Tödt onderskei die volgende ses aspekte of fasette van die proses van morele oordeelsvorming:

1 Die waarneming, aanname en bepaling van die betrokke probleem as in sedelike probleem;

2 Analise van die situasie waarin die probleem die betrokke subjekte uitdaag; 
3 Vasstelling van die moontlike vorme van gedrag wat toepaslike en morele antwoorde op die probleem sou kon wees;

4 Die uitkies en beoordeling van norme, "goedere" en perspektiewe, wat relevant sou kon wees om die keuse tussen bogenoemde moontlike vorme van gedrag, uit te oefen;

5 Die toetsing van bogenoemde keuse, dit wil sê die vasstel of die vorme van gedrag wat as moreel toepaslik beskou word, ook deur ander as morele verpligting erken kan word;

6 Die morele beslissing self.

Tödt bied van elkeen van hierdie fasette 'n uitvoerige verduideliking:

2.1 Allereers, sê Tödt, speel die waarneming, die aanname en die nadere bepaling van die betrokke probleem as 'n sedelike probleem, 'n sleutelrol. Die sedelike oordeelsvorming word aan die gang gesit deur die konfrontasie met 'n konkrete probleem. Indien 'n mens die probleem nie raaksien nie, of dit verdring, vind morele oordeelsvorming nie plaas nie. En indien 'n mens die probleem nie akkuraat genoeg waarneem en verstaan nie, sal die oordeelsvorming en die reaksie diffuus blys. Elkeen van die drie terme in die uitdrukking is gevolglik vir hom belangrik.

Onopgeloste spanninge of gebreke wat uit die verlede oorgebly het, kan mense uitdaag as ' $n$ konkrete probleem in die hede. Andersyds kan egter ook geantisipeer word dat 'n bepaalde ontwikkeling in die toekoms tot 'n probleem gaan lei en daarom nou reeds aangepak moet word, omdat dit op 'n later stadium dalk veel moeiliker of onmoontlik kan wees om dit dan op te los. Die eerste punt is egter dat die probleem raakgesien moet word.

Die tweede punt is dat die probleem as ' $n$ sedelike probleem aangeneem moet word. Die wêreld konfronteer ons daagliks met 'n veelvoud van konkrete probleme. Ons ervaar baie van hierdie probleme as slegs tegnies en nie as sedelik van aard nie. 'n Probleem word na Tödt se mening slegs as sedelik ervaar as die probleem die persoon wat dit waarneem onvoorwaardelik ("unbedingt") aangaan. Vanselfsprekend, sê hy, kan ons nie alle probleme in die wêreld en die samelewing as ons eie aanneem nie. Ons is gedwing om te kies. Tog is dié keuses wat ons uitoefen ook weer nie om 't ewe, asof ons maar kan kies wat ons wil en laat wat ons wil nie. Ook die keuse self is 'n morele saak. As mense hulle byvoorbeeld so volledig toewy aan probleme wat ver van hulle af lê, en om dié rede mense en probleme wat naby hulle lê en wat volledig hulle verantwoordelikheid is, buite rekening laat, is daar 'n element van skuld 
aan verbonde. Dus: reeds die keuse van sedelike probleme wat ek as my eie probleme en my eie verantwoordelikheid aanneem, is 'n vraag van morele oordeelsvorming.

Die derde punt word goed duidelik wanneer meerdere mense saam 'n gemeenskaplike morele oordeel moet ontwikkel oor 'n gemeenskaplike uitdaging. Dit is dan van allerbeslissende belang dat hulle eers moet saamstem oor die presiese aard van die probleem waarmee hulle te make het. Meermale dink mense dat hulle oor dieselfde saak nadink en praat, maar is dit nie werklik die geval nie. Wanneer mense nie saamstem oor wat die probleem is nie, of ten onregte meen dat hulle saamstem, sal die oordeelsvorming onvermydelik ook in verskillende rigtings ontwikkel. Kortom, om in dialoog met andere 'n gemeenskaplike omskrywing van die probleem te probeer vind ("kommunikationsfähig zu werden") is self ook al 'n morele verantwoordelikheid.

Ons kan dié aspek illustreer aan die hand van die voorbeeld van armoede as morele probleem. Dit is heel moontlik dat 'n Christenekonoom dikwels in sy/haar studie van die ekonomie met die probleem van armoede - ook die probleem van armoede in die Suid-Afrikaanse konteks gekonfronteer word, maar dit nooit as 'n sedelike probleem waarneem en sy/haar eie maak nie. Hy/sy kan die probleem van armoede deurgaans waarneem en hanteer as 'n suiwer sektorale, ekonomiese probleem wat met behulp van ekonomiese analises en middele opgelos kan word. Dit kan egter gebeur dat hy/sy op 'n dag as lid van die plaaslike oorgangsraad 'n plakkerskamp besoek en dan so aangegryp word deur die ellende waarin die inwoners verkeer dat hy/sy hom/haar vas voorneem om iets aan die armoede te doen. Dit is duidelik dat die probleem van armoede daarmee vir hom/haar ook 'n sedelike probleem geword het wat hy/sy as haar eie aangeneem het.

Konfronteer die persoon daarna - in 'n eerste poging om iets aan die saak te doen - die leiers van sy/haar plaaslike kerk op 'n vergadering met die probleem, kan dit baie gou blyk dat daar onder mede-Christene uiteenlopende beskouinge oor die presiese aard van die probleem is. Dit kan wees dat daar van die leiers is wat erken dat armoede 'n groot probleem in Suid-Afrika is, maar oordeel dat dit 'n suiwer ekonomiese probleem is wat beslis nie op die terrein van die kerk lê nie. Daar kan ander wees wat erken dat armoede ' $n$ sedelike probleem is, maar eerder aangespreek voel deur die lot van 'n aantal blanke jongmense op die dorp wat na skool nie werk kon kry nie, omdat die plaaslike nywerhede verkies om swart jongmense aan te stel. Dit is duidelik dat die oordeelsvorming van die leiers van die betrokke gemeente in verskillende rigtings sal ontwikkel, tensy 
hulle deur verdere gespreksvoering tot groter eenstemmigheid kom oor wat die sedelike probleem van armoede is wat hulle gemeenskaplik aangaan.

2.2 'n Tweede aspek wat ten nouste hierby aansluit, is die nadere analise van die situasie waarin die probleem die betrokke subjekte uitdaag. Elke probleem, argumenteer Tödt, is ingebed in 'n spesifieke konteks. Hierdie diepe verworteling van die etiese probleem in sy werklikheidskonteks moet gevolglik so akkuraat as moontlik gerekonstrueer word ten einde verantwoordelike morele oordele daaroor en reaksies daarop te kan vorm.

'n Afdoende, in die sin van 'n volledige of objektiewe analise van enige konteks, is om klaarblyklike redes onmoontlik. Die eerste punt is gevolglik dat ook hier seleksie en reduksie onvermydelik is. 'n Sekere "snit" moet gemaak word uit die veel meer omvattende werklikheid. Hierdie seleksie word deur die werklikheidsbeskouinge en die bedoelinge en belange van diegene wat die situasie analiseer en beoordeel, gerig. Om dié rede is dit self 'n saak van verantwoordelikheid, en dus inherent self deel van die morele oordeelsvorming.

Die tweede punt is dat die bydrae van ander wetenskappe en interpretasieraamwerke - soos Tödt dit noem - van sleutelbelang word. Die aanvanklike nadere bepaling van die probleem word deur meer spesifieke kennis aangaande die situasie gekorrigeer, sodat nuwe definisies kan ontstaan. Opnuut duik 'n probleem egter op: ook die sogenaamde sektorale wetenskappe, wat hulle elk net met 'n sektor of deel van die werklikheid besig hou, bied self 'n onoorsigtelike aanbod aan begrippe, kategorieë, metodes en kennis. Daarby kom: indien mense vra wat byvoorbeeld die politieke wetenskap of die sosiologie of die historiese wetenskappe oor 'n spesifieke probleem te sê het, stuit hulle op botsende en onverenigbare menings. Die oomblik as ' $n$ kerklike kommissie byvoorbeeld vakkundiges insluit, word dit dramaties geilllustreer, herinner Tödt. Alles hang af van welke vakkundiges daarop dien! Ook in hierdie keuses, dit wil sê na welke wetenskappe, na welke rigtings binne die betrokke wetenskap en na welke verteenwoordigers van dié rigting geluister word, sit reeds 'n stuk verantwoordelikheid opgesluit.

Hiermee hang 'n derde punt ten nouste saam. Indien 'n situasieanalise in ' $n$ proses van etiese oordeelsvorming relevant moet wees, moet dit eenvoudig genoeg wees. Die situasie moet herlei word tot 'n soort "situasie-skema". Vereenvoudiging en veralgemening is onvermydelik. In 'n homogene situasie, waar 'n bepaalde groepsetos as vanselfsprekend geld, handel mense volgens so 'n kollektiewe, gedeelde skematisering. Hulle ken eintlik geen alternatiewe nie. In 'n heterogene, pluralistiese 
samelewing is dit egter problematies. Dan is die sosiale werklikheid ondeursigtig. Tog benodig mense in so 'n samelewing ewe-eens skemas, vereenvoudiginge en veralgemenings om hulle te help om te kan oordeel en handel. Vanselfsprekend vra die keuse vir so 'n vereenvoudigende interpretasie, van wat waarlik op die spel is, verantwoordelikheid. Dit kan immers meer verduister as verhelder, meer mislei as leiding gee. Die keuse self is gevolglik ' $n$ sedelike handeling, met ingrypende konsekwensies vir die verdere fasette van die morele oordeelsvorming.

'n Vierde punt is hier van belang. 'n Onontbeerlike deel van hierdie skematiserende analise van die situasie is ' $n$ insig in die ontstaan van die probleem, in wat Tödt die "genetiese samehange" noem. Die aard van die problematiek word mede-bepaal deur die voortwerking van die verlede in die hede. Wie dit verontagsaam, misken die ware aard van die uitdaging en sal nie tot ' $n$ verantwoordelike beoordeling en reaksie kan kom nie.

Om terug te keer na ons voorbeeld: Gestel die kerkraad of gemeenteraad stem uiteindelik saam dat die armoede in die plaaslike plakkergemeenskap 'n morele probleem is wat hulle aangaan en besluit om 'n kommissie van ondersoek na dié probleem in die lewe te roep. Dié kommissie oordeel dat hulle slegs 'n verantwoorde voorstel oor die regte optrede kan maak as hulle eers 'n behoorlike situasie-analise gedoen het.

Dit is eerstens duidelik dat die resultaat van die situasie-analise in ' $n$ belangrike mate sal afhang van wie almal in die ondersoekkommissie dien. Die situasie-analise van 'n kommissie wat uit predikante, maatskaplike werkers, mediese dokters en onderwysers bestaan, sal beslis anders lyk as die situasie-analise van een wat slegs uit plaaslike sakelui en 'n afgetrede demograaf saamgestel is. Tweedens sal die situasie-analise afhang van hoe wyd die kommissie hul visier stel, of hulle die situasie ten aansien van behuising en/of werkloosheid, wanvoeding, geletterdheid, misdaad, dwelmverslawing, tienerswangerskappe, prostitusie, kindermishandeling, ensovoorts in die plakkergemeenskap wil analiseer. Hulle sal noodgewonge 'n keuse moet maak om slegs 'n sekere aantal van hierdie faktore te analiseer. Watter seleksie van faktore is nou egter moreel verantwoord? Om byvoorbeeld te konsentreer op die faktore van misdaad, dwelmverslawing en tienerswangerskappe en faktore soos behuising en werkloosheid te ignoreer, sou - vanuit morele gesigspunt besien - beslis verdag voorkom. Derdens sal die situasie-analise ook afhang van hoe in diepte hulle elkeen van die faktore wat hulle uitsonder, ondersoek. Volstaan hulle byvoorbeeld in verband met werkloosheid met die verkryging van syfers wat 'n aanduiding gee van die omvang van werkloosheid in die plakkerkamp of delf hulle ook dieper om 'n beeld te kry van die oorsake van dié 
werkloosheid? En is hulle dan ook bereid om die bydrae wat die toepassing van die apartheidsbeleid tot die ontstaan van die probleem van werkloosheid (en ander armoedeverskynsels) gelewer het, in oënskou te neem?

2.3 Die derde faset is die vasstelling van die moontlike vorme van gedrag wat toepaslike en morele antwoorde op die probleem sou kon wees.

Die eerste punt in hierdie verband is van sleutelbelang. Moontlike reaksies, moontlike vorme van gedrag, kom allereers as "ontwerp" ter sprake. In dié "ontwerpe" ontwerp mense egter tegelyk ook hulleself, hulle eie lewens, karakters en identiteit. Hulle ontwerp daarin 'n stuk van hulle eie lewens. Hulle gedrag kan nie losgemaak word van wie hulleself is nie. As hulle vra: Welke moontlikhede van gedrag bestaan daar ten aansien van hierdie probleem? vra hulle eintlik: Welke moontlikhede van reaksie bestaan daar vir ons, sodat ons getrou bly aan onsself, aan wie ons is en wil wees? Daar kan vorme van pragmatiese reaksie wees wat oënskynlik baie effektief kan wees, maar sedelik nie verantwoordbaar is nie, omdat hulle verwoestende uitwerkinge kan hê op die gewete, die identiteit en die integriteit van die individu of die groep.

Daarmee keer Tödt hom baie uitdruklik teen die tipies moderne neiging om slegs te soek na pragmatiese en tegniese oplossings vir uitdagings en probleme. Vir die moderne lewensgevoel skyn dit naamlik asof vele probleme slegs waardevrye, tegniese oplossings verlang, waarby sedelikheid of etiek geen rol speel nie. Dit weerspieël die tipies modernistiese opbreek van die lewenswerklikheid in geïsoleerde sektore of kompartemente, elk met hulle eie wetmatighede en vanselfsprekendhede. Watter gedrag nodig en van pas is, is hiervolgens alreeds gegee met die wetmatighede self.

Dié lewensgevoel, meen hy, berus egter op totaal valse veronderstellings. Die sosiale lewenswêreld is gevul met onsekerhede en teenstrydighede. Dit ontwikkel nie wetmatig en vanselfsprekend in die toekoms in nie, maar moet juis voortdurend ontwerp en verder ontwikkel word. Wat ook al fakties in die wêreld mag geld, sê hy, die toekoms is ook die saak van mense. Elke houding of handeling aan ons kant beïnvloed die toekoms. Om dié rede moet ons voortdurend verantwoordelikheid aanvaar en onsself afvra hoe die skynbaar pragmatiese, selfs tegniese oplossings wat ons op korttermyn so vanselfsprekend mag ag, op die lange duur die toekoms gaan beïnvloed en derhalwe sedelik beoordeel moet word. Ook voorstelle (of ontwerpe) vir moontlike oplossings vir sektorale probleme moet gevolglik 
beoordeel word in die lig van hul moontlike betekenis vir 'n menslike toekoms. Elke enkeling kry deur haar of sy gedrag deel aan die gevolge daarvan vir die toekoms en daarom most ons gedrag verantwoord kan word.

Hieruit vloei 'n tweede punt. Die gevolge van ons gedrag in die toekoms bly uiteindelik ondeursigtig. Gedrag het altyd onvoorsiene gevolge - en meermale is dié veel belangriker as die gevolge wat ons wel voorsien het! Dit beteken egter dat ons morele oordeelsvorming stuit op die grense van ons onvermoë om vooruit te kan sien en te kan weet. Dit impliseer dat ons meesal nie te make het met keuses tussen eenduidig goed en eenduidig sleg nie, maar met die afweeg van welke beslissing en optrede die sedelike voorkeur bo die ander verdien.

Dit lei weer tot ' $n$ derde punt. Om in die aangesig van hierdie problematiek - dat ons nie maklik kan onderskei tussen goed en sleg, tussen goeie gevolge en slegte gevolge nie - niks te doen nie, beklemtoon Tödt, is self ' $n$ beslissing. Besluiteloosheid (om nie te sê belangeloosheid en onverskilligheid nie) is meestal 'n gebrekkige en onverantwoordelike keuse.

Om hierdie rede is die omgang met skuld ' $n$ integrale deel van die proses van morele oordeelsvorming en 'n fundamentele probleem van die sedelike lewe. Om wat sleg is bewus op jou te neem, impliseer skuld. Om onbewus - kwaad aan te rig, verwikkel 'n mens objektief in skuld. Reeds die situasie-analise, wat ons verplig is om te maak, berus op die waagstuk dat ons 'n fout kan maak. Om dan die situasie boonop nie so sorgvuldig moontlik te wil leer ken nie, om nie alle moontlike vorme van gedrag te wil oorweeg nie en om doelbewus nie alle moontlike gevolge vir die gemeenskaplike toekoms in ag te wil neem nie, is almal vorme van nalatigheid en onverantwoordelikheid.

Om dit wat sopas gesê is, te knoop aan ons voorbeeld: Dit is ooglopend dat die vorme van gedrag wat as toepaslike antwoorde op die armoedeprobleem van die plakkers deur die kommissie geïdentifiseer sal word ten nouste saamhang met die situasie-analise wat dit voorafgegaan het. Die optrede wat 'n kommissie sal voorstaan wat slegs uit sakelui en 'n afgetrede demograaf bestaan en in hul situasie-analise volstaan met 'n statistiese beeld van die hoë voorkoms van misdaad en tienerswangerskappe, sal verseker verskil van 'n kommissie wat maatskaplike werkers en dokters insluit en bereid is om te kyk na die behuisings- en werkloosheidsprobleme en die bydrae wat apartheid daartoe gelewer het. Dit is nie uitgesluit nie dat eersgenoemde kommissie sulke drastiese maatreëls soos 'n aandklokreëling om misdaad te bekamp en die verpligte inspuiting van 
alle tienermeisies in die plakkerkamp met 'n langwerkende geboortebeperkende middel om tienerswangerskappe te beperk, sal bedink nie. Laasgenoemde kommissie kan dalk vorendag kom met voorstelle soos dat die gemeente 'n stuk grond wat hy besit, vir die oprigting van laekoste behuising vir die plakkers tot beskikking stel en dat alle werkgewers in die omgewing aangemoedig moet word om ten minste vir 'n sekere tydperk by aanstelling voorrang te verleen aan geskikte swartmense om wanbalanse van die verlede uit die weg te ruim en die werkloosheidsprobleem onder swartmense te verlig.

Dat dit enigsins voorstelbaar is dat 'n kerklike kommissie met drastiese voorstelle soos verpligte geboortebeperkende inspuitings vir tienermeisies vorendag kan kom, illustreer twee punte wat Tödt maak. Die eerste is dat daar steeds weer die neiging bestaan om suiwer pragmatiese oplossings vir probleme te formuleer sonder om die sedelike implikasies van hierdie voorstelle in ag te neem. $\mathrm{Om}$ ' $\mathrm{n}$ tienermeisie teen haar sin met ' $n$ geboortebeperkende middel in te spuit, mag effektief wees, maar is dit menslik? Die tweede is dat die gedragsmoontlikhede wat mense ontwerp, ten nouste saamhang met wie hulle is. Laasgenoemde word weer in 'n belangrike mate bepaal deur godsdienstige en morele oortuiginge wat mense daarop nahou. Ander faktore soos hul opleiding, sosiale status, geldelike belange en ideologiese verbintenisse speel egter ook ' $n$ bepalende rol en dikwels selfs 'n oorheersende rol.

Selfs al slaag mense egter daarin om in hul keuse van toepaslike gedragsvorme morele oorwegings die botoon te laat voer, beteken dit nie soos Tödt tereg beklemtoon - dat hul keuse eenduidig goed is nie. 'n Keuse soos regstellende aksie illustreer dit wat Tödt sê, baie duidelik. Selfs in die beste gevalle is daar met regstellende aksie mense wat skade ly en met reg kan voel dat daar teen hulle gediskrimineer word. Regstellende aksie is in gegewe situasies, vanuit morele gesigspunt besien, egter die mees toepaslike wyse om wanbalanse van die verlede in 'n mate reg te stel.

2.4 Die volgende voor-die-hand-liggende aspek is die uitkies en beoordeling van "norme, goedere ("Güter") en perspektiewe", wat relevant sou kon wees om die keuse tussen bogenoemde moontlike vorme van gedrag, as antwoord op die probleem, uit te oefen. Hoe weeg 'n mens uiteindelik die moontlike reaksies op die uitdaging sedelik? Op grond waarvan verkies 'n mens een bo die ander? Tödt praat van "norme, goedere en perspektiewe".

'n Eerste stelling wat Tödt maak, is dat norme in die reël benut word om uitsluitsel tussen verskillende moontlike gedragsvorme te gee. Self 
beskryf hy norme as "die sedelik relevante reëls wat aanspraak maak om in sosiale verhoudinge nagevolg te word". Wanneer mense met 'n sedelike probleem gekonfronteer word, moet die betrokke norme wat lyk asof hulle op dié saak van toepassing is, in werking gestel word. Watter norme werklik van toepassing sou wees, veral wanneer meerdere konflikterende norme toegepas sou kon word, of wanneer duidelike norme vir dié soort situasie nog nie voorhande is nie, is dikwels baie moeilik uit te maak.

Wat sake kompliseer, is dat morele norme, selfs in die mees gunstige omstandighede, nie die enigste normerende faktor in die keuse tussen verskillende handelingsmoontlikhede is nie. Mense ontvang ook leiding en rigting deurdat hulle in sosiale instellinge en verbande leef; asook daardeur dat hulle status, sosiale posisie en openbare rolle hulle help om te besluit en te handel. Dit is nie maar net dat die aansprake van morele norme en van sosiale instellinge en rolle dikwels met mekaar in kompetisie is nie. By baie besluite kan daar nie maklik 'n onderskeid gemaak word tussen norme enersyds en instellinge en rolle andersyds nie. Die verwagtinge wat institusies en rolle met hulle meebring en die verbindende $\mathrm{krag}$, die verpligting, wat hulle uitoefen, word meermale as norme verstaan en ervaar.

Die tweede punt is nou dat norme (ook al sluit ons daarby instellinge en rolle in) nie al faktor is wat ' $n$ rol speel in die keuse tussen verskillende gedragsvorme nie. Ook die opweeg van "goedere", sê Tödt, vervul 'n aansienlike funksie. Daarmee bedoel hy die volgende. Die mens, as wese met behoeftes, benodig sekere "goedere" en streef daarna om dié goedere te bekom en dié behoeftes te bevredig. Aangesien daar 'n tekort aan baie sodanige goedere heers, ontstaan mededinging en stryd. Wat om na te streef en wat nie, wat om te doen en wat nie, word in 'n belangrike mate bepaal deur die lewensbeperkinge waaronder ons verplig is om besluite te neem en te handel. Ons is nie vry om in ons oordeelsvorming en ons beslissings net uit te gaan van norme en sosiale verwagtinge en rolle nie. Dié oorwegings word steeds ingeperk en beïnvloed deur ons basiese behoeftes, ons begeertes en verlangens, die reële tekorte wat daar heers en die mededinging en konflik wat daardeur veroorsaak word.

Dit lei tot ' $n$ derde punt. Diegene wat 'n morele beslissing moet vel oor wat hulle in 'n gegewe situasie te doen staan, word dikwels oorweldig deur 'n veelvoud van aansprake wat meermale ook nog met mekaar bots. Norme bots met mekaar. Verskillende "goedere" wat nagejaag kan word, bots met mekaar. Norme bots met die najaag van goedere. Mense benodig gevolglik nog iets meer, te wete wat Tödt "perspektiewe" noem. Hulle benodig oorsigtelike samehange, interpretasiekaders, uitgangspunte, wat 
hulle kan help om hierdie botsende norme en goedere tegelyk in die oog te kry en waarlik te kan oorweeg. Uiteindelik is dit die geheel-perspektief van persone wat hulle help om te kies tussen die veelvoud van (botsende) norme en goedere. Die mens se uitsig op die wêreld, die identiteit van die mens, die karakter, die visie, die grondrigting van sy of haar bestaan bepaal aan welke norme en goedere hulle gaan voorkeur gee wanneer hulle moet kies tussen moontlike vorme van gedrag.

Om terug te keer na ons voorbeeld toe: Aangesien die lede van die kommissie tot dieselfde kerkgenootskap behoort, is dit hoogs waarskynlik dat hulle in die keuse van toepaslike gedragsvorme morele norme sal benut wat uit 'n gemeenskaplike poel van morele norme kom. Was die kommissie egter saamgestel uit verteenwoordigers van verskillende kerkgenootskappe of konfessies, was dit nie noodwendig die geval nie. Protestantse lede van so 'n ekumeniese kommissie sou geneig wees om slegs "Bybelse" norme te benut, terwyl Rooms Katolieke lede ook van natuurregtelike norme gebruik sou maak.

Ook al put ons kommissie van die plaaslike gemeente uit 'n gemeenskaplike poel van morele norme, is dit nie te sê dat hulle almal van dieselfde norme gebruik sal maak nie. Die een lid mag dalk daarvan oortuig wees dat Bybelse barmhartigheidsnorme vir die morele probleem van armoede relevant is, terwyl 'n ander weer mag oordeel dat Bybelse geregtigheidsnorme relevant is.

Tot die kommissielede se keuse van 'n toepaslike optrede lewer egter nie net die aansprake van (moontlik verskillende) morele norme 'n bydrae nie, maar ook die aansprake van die sosiale instellinge waartoe hulle behoort en die aansprake van die "goedere" waaraan hulle 'n behoefte het. Behoort die lede van die kommissie tot verskillende politieke partye, volksverbande, kultuurorganisasies, en/of ekonomiese organisasies (sommige tot werkgewers- en ander tot werknemersorganisasies) en het die lede boonop nog behoefte aan heel uiteenlopende "goedere" (sommige aan basiese dinge soos voedsel, skoon water en 'n dak oor hul kop en ander aan die dinge wat 'n hoë lewenspeil kenmerk), is die kans goed dat hul nie dieselfde optrede as gepas sal beskou nie. Hoe meer die kommissielede tot dieselfde sosiale instellinge en verbande behoort en hoe meer hulle aan dieselfde "goedere" behoefte het (soos dit die geval is in baie welvarende, oorwegend blanke, voorstedelike gemeentes), hoe meer waarskynlik is dit dat hulle sal saamstem oor die gepaste optrede. Die gevaar dat hulle 'n optrede sal voorstel wat vir die inwoners van die plakkerskamp heeltemal onvoldoende of selfs onaanvaarbaar is, is dan egter soveel groter. Daarmee is beslis een van die redes vir die mislukking van die inisiatiewe van soveel gemeentes om armoede te bestry, geïdentifiseer. 
Uiteindelik sal die perspektiewe wat die lewe van die kommissielede beheers, die mees beslissende invloed hê op watter optrede hul as die mees toepaslike voorstaan. Dit is reeds by voorbaat duidelik dat ' $n$ kommissielid wat 'n sterk Afrikanernasionalis is, nie juis 'n voorstander van optrede sal wees wat van die gemeente baie geld en moeite vra en die belange van Afrikaners in die gedrang kan bring nie. 'n Kommissielid wat 'n piëtistiese beskouing van die verlossing in Christus het, sou waarskynlik voorstel dat eerder sendingwerk as ontwikkelingswerk in die plakkerskamp onderneem word. Beskou ' $n$ bepaalde kommissielid die verlossing in Christus egter as 'n omvattende transformasie wat alle aspekte van die menslike lewe - die geestelike en die materiële aspekte - raak, sal hy of sy 'n sterk voorstander wees van 'n omvattende opheffing van die plakkergemeenskap.

2.5 Dit bring ons by die vyfde aspek, te wete die toetsing van die vraag of die gedrag wat as toepaslik beskou word, en ook deur ander as sedelike verpligting erken kan word

Die vertrekpunt is vir Tödt hier die eenheid van mens-wees. By hom beteken dit egter iets anders as by Kant. In Kant se moraalfilosofie berus die noodsaak van gedeelde morele oordele natuurlik op die veronderstelling dat 'n standpunt en optrede slegs as "sedelik" kwalifiseer indien die riglyn ("die Maxime") wat daaraan ten grondslag lê in ooreenstemming is met die "wet" ("Gesetz") wat as objektiewe beginsel vir elke rasionele mens ("versele rede" dus die metafisiese begronding vir die praktiese noodsaak om etiese oordele te kontroleer met ander rasionele, morele agente.

Vir Tödt is dit duidelik dat so ' $n$ metafisiese begronding in ' $n$ universele en tydlose rasionaliteit vandag nie meer moontlik is nie, vanweë die wydverbreide erkenning van die historisiteit van alle gestaltes van redelikheid. Die veronderstelde eenheid van die mensheid word verduister deur die historiese werklikheid van vervreemding, sowel in as tussen mense, wat na die oordeel van die Christelike geloof in die sonde verwortel is.

Desondanks wil hy aan die uitgangspunt vashou dat oordele slegs dan sedelik "in die volle sin van die woord" kan wees, indien dit tog die indruk wek ("die Aussage provozieren") dat elke mens, in dieselfde situasie en onder dieselfde historiese lewensomstandighede, hom of haar so behoort te gedra as wat die morele oordeel waarop besluit word, gebied. Die uitgangspunt berus by hom nie meer, soos in die tradisie van Kant, op die veronderstelling van die rasionele natuur van die mens nie, maar op die 
verantwoordelikheid van die een wat oordeel om mens te wees saam met ander mense.

Kortom, hy begrond die noodsaak om enige morele oordeelsvorming te kontroleer aan andere nie in 'n idealistiese etiek nie, maar in 'n verantwoordelikheidsetiek. As mense wat in die wêreld en die geskiedenis saam met ander mense leef, leef ons steeds onder die konkrete verantwoordelikheid om op te tree op wyses wat hulle instemming sou wegdra 6 . By elke vorming van 'n morele oordeel, sê Tödt, moet gevolglik in gedagte gehou word dat die subjektiwiteit van die persoon wat die oordeel fel of van die groep wat die keuse gesamentlik maak, nie die veralgemening van hul oordeel of keuse onmoontlik maak nie.

Die veronderstelling waarop hierdie verpligting tot kontrole berus, is volgens Tödt dat vryheid as "kommunikatiewe vryheid" verstaan moet word?. Dit beteken eenvoudig dat individue die vryheid van andere nie soos in liberale tradisies - moet ervaar as ' $n$ inperking van die eie vryheid nie, maar juis as die moontlikheid tot egte vryheid. Juis daarin dat ons nie op onsself aangewys is nie, maar vry is om saam met andere en in kommunikasie met hulle, te soek na die regte besluite, ontvang ons die vryheid om te leef en te doen.

Dit alles is natuurlik besonder relevant vir die voorbeeld wat ons bespreek het. Reeds met die bespreking van die vorige aspek van die proses van morele oordeelsvorming het ons daarop gewys dat 'n kerklike kommissie maklik tot 'n bepaalde optrede in die bestryding van armoede kan besluit wat vir ander - ook vir diegene wat in armoede verkeer ontoereikend of onaanvaarbaar is. Dit is daarom noodsaaklik dat die kommissie so goed moontlik sal vasstel of die optrede wat hulle moreel toepaslik ag, ook deur ander as sodanig erken kan word. Die mees voordie-hand-liggende en ook mees effektiewe manier is om so wyd as moontlik te konsulteer: met ander gemeentes, met Christene uit ander konfessies, met ekumeniese organisasies en veral met die inwoners van die plakkerskamp. Trouens, die beste manier om te verseker dat hul keuse van toepaslike optrede nie op weerstand in die geledere van die plakkergemeenskap stuit nie, is om van die begin af verteenwoordigers van dié gemeenskap in die kommissie te betrek, of op 'n deurlopende basis te konsulteer.

2.6 Oor die sesde stap, te wete die morele beslissing self, hoef vir ons doel nie meer gesê te word nie as dat daarmee kognitiewe insig (gebaseer op oorweginge aan die ander stappe ontleen) en wilsbesluit (om 'n bepaalde optrede as die sedelik mees aanvaarbare te kies) saamvloei. Met dié morele 
beslissing onderneem die betrokke persone om dienoorkomstig op te tree. Daarmee bevestig hulle by implikasie dat die gekose optrede aansluiting vind by hul eie identiteitsbesef.

\section{SLOTOPMERKING}

In die voorafgaande bespreking, so hoop ons, het ons duidelik geillustreer dat Tödt se uiteensetting van die verskillende aspekte of fasette van die proses van morele oordeelsvorming, ons help om te begryp waarom Christene in konkrete situasies so verskil oor wat die wil van God is. Dit het uit die bespreking hopelik duidelik geword dat Tödt se uiteensetting van dié aspekte 'n nuttige hulpmiddel bied om in 'n gesprek oor wat in 'n gegewe situasie die juiste morele optrede is, vas te stel wat die faktore is waaroor eers duidelikheid verkry moet word, voordat 'n verantwoorde morele beslissing geneem kan word.

\section{NOTAS:}

1 Vergelyk A A van Ruler, "Structuurverschillen tussen het christologische en het pneumatologische gezichtspunt", in J de Graaf (red), De Spiritu Sancto. Bijdragen tot de leer van de Heilige Geest, Utrecht 1964, 205-227.

2 In Suid-Afrika het D E de Villiers reeds in sy 1978-proefskrif, Die eiesoortigheid van die Christelike moraal, Amsterdam, 175-176, juis in aansluiting by Tödt se eerste bydrae van hierdie aard, die proses van etiese oordeelsvorming baie kortliks gerekonstrueer. In sy (ongepubliseerde) 1986-navorsingsverslag aan die RGN, "'n Analise van kerklike kritiek teen die Suid-Afrikaanse samelewing in die buiteland", maak De Villiers meer uitvoerig gebruik van so 'n skematisering en die faktore daaraan verbonde. Hy onderskei tussen vyf tipes faktore wat beoordeling beïnloed, te wete "probleembewussyn en situasieanalise, besluitneming oor optrede, lewens- en wêreldbeskoulike oortuiginge, belange en verbintenisse, historiese omstandighede". Met behulp van hierdie faktore, wat ook in 'n skets uitgebeeld word, analiseer hy dan die stof.

In sy artikel "Tussen simpatie en veroordeling. Buitelandse kritiek teen apartheid (1948-1985)", in: Koninkryk, kerk en kosmos, Bloemfontein 1989, 144-163, behandel De Villiers nogeens hierdie gedagtes, en juis na aanleiding van die vraag: "Die uiteenlopende en selfs teenstrydige standpuntinname van kerke ten opsigte van apartheid roep onwillekeurig die vraag op: waarom oordeel mense wat dieselfde geloof in Jesus Christus bely so verskillend?"

In die bekende verslag van die Gereformeerde Ekumeniese Raad oor "Hermeneutics and ethics" (October 1990), 'n poging om vas te stel waarom kerke wat almal van gereformeerde oorsprong en oortuiging is en almal dieselfde Skrifte 
lees en as gesaghebbend beskou so ingrypend van mekaar verskil in hulle gevolgtrekkings en hulle standpuntinnames oor homofilie, word gedeeltelik aan hierdie saak aandag gegee.

In sy artikel oor Skrifgebruik in die etiek, "oor 'Nuwe Testamentiese etiek', die Christelike lewe en Suid-Afrika vandag", in: Geloof en opdrag. Perspekriewe op die etiek van die Nuwe Testament, Scriptura S9a (reds C Breytenbach \& B C Lategan), 1992, 303-325, illustreer D J Smit hierdie problematiek kortliks aan die hand van die homofilie-debatte binne die GER.

Onlangs het $\mathrm{J}$ A Heyns hieroor geskryf in "Enkele opmerkinge oor die proses van kontemporêre etiese beslissinge", NGTT XXXIII/3 (1992), 364-372 en J H van Wyk in Moraliteit en verannwordelikheid. Opstelle oor politieke etiek, Potchefstroom 1991, veral 17-37, maar beide gaan van ander benaderings uit.

3 Sy belangrikste bydraes is: "Versuch zu einer Theorie ethischer Urteilsfindung", ZEE 21 (1977), 81-93; "Versuch einer ethischen Theorie sittlicher Urteilsfindung" en "Die Zeitmodi in ihrer Bedeutung für die sittliche Urteilsbildung", Perspektiven theologischer Ethik, München 1988, 21-48 en 4985 onderskeidelik.

Vir bydraes in gesprek met Tödt, sien W Huber, "Strukturen verantwortichen Lebens. Die Bedeutung Heinz Eduard Tödts für die theologische Ethik", Vortrag bei der akademischen Gedenkfeier in Heidelberg am 6. Mai 1992; die hele feesbundel van Chr Frey/W Huber (Hrsg), Schopferische Nachfolge. Festschrift für Heinz Eduard Todt, Heidelberg 1978; asook O Höffe ("Bemerkungen zu einer Theorie sittlicher Urteilsfindung”, 181-187), Chr Link (Überlegungen zum Problem der Norm in der theologischen Ethik", 188-199), C Frey ("Humane Erfahrung und selbstkritische Vernunft", 200-213), almal in ZEE 22 (1978); $\infty$ k nog $\mathrm{H}$ Ringeling, "Ethische Normativität und Urteilsfindung”, ZEE 28 (1984), 402-425; A Rich, Wirtschafisethik Bd. I, Gütersloh 1984, 224-228; ook Chr Frey, Theologische Ethik, Neukirchen 1990, 229-239.

Daar is sedertien egter talle ander werke oor die tema gepubliseer. Vergelyk byvoorbeeld H Ruh, Argument Ethik, Zürich 1991, veral $329 \mathrm{ev;} \mathrm{W} \mathrm{Bender} \mathrm{se}$ uitstekende werk, Ethische Urteilsbildung, Stuttgart 1988; E Herms, "Grundlinien einer Theorie der Bildung von ethischen Vorzüglichkeitsurteilen", Gesellschafi gestalten, Tübingen 1991, 44-55; D Lange, Ethik in evangelischer Perspekrive, Göttingen 1992, 487-521; cok M Honecker, “Exkurs: Zur Methode ethischer Urteilsfindung", Einfuhrung in die Theologische Ethik, Berlin 1990, 208-210.

4 Uit die literatuur by die vorige notas genoem, is dit duidelik dat daar talle maniere is om hierdie aspekte te numereer en te rangskik. Verskillende skrywers werk met verskillende benaderings. Juis aangesien Tōdt die geleentheid gehad het om sy eie analise $\infty$ r jare heen te verskerp, in gesprek met kollegas en navolgers wat daarop gereageer het, vind ons dit nuttig om daarby aan te sluit ter wille van gesprek. 
5 In 'n kritiese - en na ons oordeel problematiese - gesprek met Tödt het J Fischer hierdie gedagtes verder uitgebou in sy "Wahmehmung als Proprium und Aufgabe christlicher Ethik", in: Glaube als Erkenntnis. Zum Wahmehmungscharalter des christlichen Glaubens, Mūnchen 1989, 91-118.

6 Op hierdie punt sluit die vele hedendaagse Duitse etici, wat uitgaan van 'n "verantwoordelikheidsetiek", by Tödt aan. Kyk byvoorbeeld J Fischer, "Christliche Ethik als Verantwortungsethik?", EvTh 52 (1991), 114-128; G Picht, “Der Begriff der Verantwortung”, Hier und Jetzr, Bd. I, Stuttgart 1980, 202-217; W Huber, "Sozialethik als Verantwortungsethik", Konflikt und Konsens, Mūnchen 1990, 135-157; “Auf dem Weg zu einer Ethik der Verantwortung", "n voordrag by "n konferensie or "Realism and responsibility in contemporary ethics" by die Divinity School van die University of Chicago op 28 Februarie 1992; W Lienemann, -Das Prinzip Verantwortung in der ökumenischen Sozialethik", in: Elhik in der europaischen Kultur, Bd.II, S Pfürtner (Hrsg.), Stuttgart 1988, 166-177. Hulle sluit feitlik almal aan by Max Weber, by Diederich Bonhoeffer (veral -Die Struktur des verantwortlichen Lebens", Ethik, München 1991; kyk die tema van 1992 se sesde jaarvergadering van die internasionale Bonhoeffer-studiegroep, "Theology and the practice of responsibility", USQR 46, 1-4, en by Hans Jonas, Das Prinzip Verantuortung, Frankfurt 1979.

7 Die term word ontleen aan die werk van die filosoof $M$ Theunissen, veral sy Sein und Schein. Die kritische Funkrion der Hegelischen Logik, Frankfurt/M 1978 , vergelyk $37 \mathrm{ev}$, asook $433 \mathrm{ev}$. 